\title{
CHARACTERISTICS OF NITROGEN AND OTHER IMPURITIES IN DIAMOND, AS REVEALED BY INFRARED ABSORPTION DATA
}

\author{
FELIX V. KAMINSKY ${ }^{\S}$ \\ KM Diamond Exploration Ltd., 815 Evelyn Drive, West Vancouver, British Columbia V7T 1J1, Canada
}

GALINA K. KHACHATRYAN

Institute of Diamonds, Russian Academy of Natural Sciences, 155 - 5/10 Litovskii Boulevard, Moscow, 117593, Russia

\begin{abstract}
Diamond crystals from Siberian, Arkhangelsk, South African, Canadian and South American deposits were analyzed for structurally bound nitrogen, hydrogen and "platelet" defects using infrared (IR) absorption spectroscopy. Wide variations in total nitrogen and hydrogen contents and in the state of nitrogen aggregation were established in diamond crystals from different areas and deposits. On this basis, three groups were distinguished: (1) low-nitrogen, highly-aggregated-nitrogen diamond, (2) intermediate diamond crystals, and (3) high-nitrogen, poorly-aggregated-nitrogen diamond (occasionally with high concentrations of hydrogen and "platelets"). They represent, in general terms, three major stages of diamond formation: (1) the initial stage at high P-T conditions, which occasionally occurs in super-deep areas (e.g., lower mantle and transition zone), (2) the main stage, and (3) the final stage, which represents the latest episodes of magmatic evolution and is characterized by high oversaturation of the crystallization medium and high internal temperature-gradients. These data may be used for "fingerprinting" of diamond, in prospecting for new deposits in diamondiferous areas, and in the evaluation of diamond crystals from newly discovered deposits.
\end{abstract}

Keywords: diamond, nitrogen, hydrogen, infrared absorption.

\section{SOMMAIRE}

Une collection de cristaux de diamant provenant des gisements de Sibérie, Arkhangelsk, Afrique du Sud, Canada et Amérique du Sud a été analysée par spectroscopie infrarouge afin d'établir les teneurs en azote et en hydrogène, et la proportion de défauts en "plaquettes". Nous avons trouvé de grandes variations en teneurs globales d'azote et d'hydrogène, ainsi qu'en état d'aggrégation de l'azote dans les cristaux provenant des différentes régions et de différents gisements. A la lumière de ces mesures, nous distinguons trois groupes: (1) diamant à faible teneur et degré d'aggrégation élevé d'azote, (2) diamant ayant des caractéristiques intermédiaires, et (3) diamant à forte teneur et à faible degré d'aggrégation d'azote (et, dans certains cas, à teneurs élevées en hydrogène et en "plaquettes"). Ces trois groupes représenteraient, en termes généraux, trois stades majeurs de formation du diamant: (1) le stade initial, à des conditions de $\mathrm{P}$ et de $\mathrm{T}$ élevées, dans certains cas correspondant à des régions très profondes du manteau (par exemple, le manteau inférieur et la zone de transition), (2) le stade principal de croissance, et (3) le stade final, qui représenterait les étapes ultimes de l'évolution magmatique, avec sursaturation élevée dans le milieu de croissance et des gradients de température internes importants. Ces données peuvent servir "d'empreinte digitale" d'échantillons de diamant, dans les programmes d'exploration pour des gîtes nouveaux dans les régions diamantifères, et dans l'évaluation de cristaux de diamant des gisements récemment découverts.

(Traduit par la Rédaction)

Mots-clés: diamant, azote, hydrogène, absorption infrarouge.

$\S \quad$ E-mail address: felixvkaminsky@cs.com 


\section{INTRODUCTION}

In the past decade, considerable progress has been made in the investigation of optically active structural defects (centers) in diamond (e.g., Evans 1992, Boyd et al. 1994, 1995, Mendelssohn \& Milledge 1995, Taylor et al. 1996). Great success has been achieved in interpreting the nature of the structural defects in diamond and in developing methods of estimating the concentrations of impurity centers causing these defects. Our main goal in this study is to systematically characterize and identify distinctive features of the distribution of optically active defects in diamond crystals from different areas, and further to interpret these features in relation to particular conditions and different stages of formation of diamond in nature.

\section{BACKGROUND INFORMATION}

Historically, diamond has been grouped into two types, I and II (Robertson et al. 1934). On the basis of the ultraviolet transparency and absorption in the infrared (IR) spectra, type-I diamond contains nitrogen in a number of different forms, whereas type-II diamond is considered a "non-nitrogen" variety (i.e., containing less than 20 at.ppm nitrogen, which is not detected by infrared spectroscopy). Type-I diamond was further subdivided into type Ia and type $\mathrm{Ib}$ depending on the form that the nitrogen takes within the structure of the individual crystal. The nitrogen atoms in type-Ia diamond are present in various aggregated forms, whereas in type-Ib diamond, they are dispersed in isolated substitutional sites (i.e., one nitrogen atom replaces one carbon atom in a number of carbon sites). A good overview of this subject, along with representative infrared (IR) spectra for each type of diamond, is given by Scarratt \& Fritsh (1992).

Synthetic diamond is commonly of type Ib. In typeIa diamond, two major nitrogen aggregates are found, $\mathrm{A}$ and $\mathrm{B}$. According to current ideas, the A nitrogen center involves a pair of nitrogen atoms jointly replacing a single carbon atom (Davies 1976, Sobolev 1978), whereas the B defect is an aggregate of nitrogen atoms tetrahedrally arranged around a vacancy (Bursill \& Glaisher 1985). On the basis of the predominance of A or B centers, this type of diamond is categorized into two subdivisions, type IaA and type $\mathrm{IaB}$, respectively. The majority of natural diamond crystals belong to the transitional IaAB type.

Infrared spectroscopy provides a means of estimating the concentrations of nitrogen (A and $\mathrm{B})$ and hydrogen $(\mathrm{H})$ impurity centers and "platelets" $(\mathrm{P})$, i.e., the optically active defects that are most characteristic of diamond. The "platelets" (P centers) are linear defects several atoms thick (Woods 1986), and the H centers are structural defects involving hydrogen (Sobolev \& Lisoivan 1971, Woods \& Collins 1983). The increas- ingly widespread use of IR spectroscopy in the investigation of natural samples of diamond was promoted largely by the refinement of the analytical relationships that are involved in the calculations of the concentration of A and B defects in diamond (Boyd et al. 1994, 1995).

The newly obtained data have proven to be of great interest from a genetic standpoint as they provide a much better insight into the conditions of diamond formation. Of particular importance is an analysis of the kinetics of transformation of nitrogen impurities based on experimental data and estimates of the time and temperature parameters at the source (Evans 1992, Taylor \& Milledge 1995, Taylor et al. 1996).

Most present-day studies of impurities in diamond contain data on diamond parageneses and carbon isotope composition (Taylor \& Milledge 1995, Meyer et al. 1997, Menzies et al. 1998, Chinn et al. 1998, Davies et al. 1999). These comprehensive studies have revealed that occurrences of nitrogen-free (type IIa) and nitrogenpoor ("low-nitrogen") diamond crystals are related to an ultramafic paragenesis, whereas in the eclogitic paragenesis, diamond is characterized by a higher-thanaverage content of nitrogen. A peculiar feature of diamond crystals from the Newlands and Jagersfontein kimberlites in South Africa is an above-average proportion of type-IIa diamond crystals (up to $60 \%$ in the Jagersfontein pipe), and the predominance of pure type-IaA diamond crystals and crystals with a low degree of nitrogen aggregation among nitrogen-rich diamond crystals (Menzies et al. 1998, Chinn et al. 1998). Examination of optically active defects in diamond crystals of the newly discovered super-deep paragenesis (with ferroan periclase + magnesium-substituted perovskite and other specific inclusions) reveals that the diamond is predominantly of type IIa (Hutchison et al. 1999, Harte et al. 1999, Davies et al. 1999, Kaminsky et al. 2001).

Concurrent with the investigation of macrocrystals of diamond $(>1 \mathrm{~mm})$, studies of structural defects in microdiamonds ( $<1 \mathrm{~mm}$ or $<0.5 \mathrm{~mm}$ ) have been carried out in the past few years (Lee et al. 1995, Leahy \& Taylor 1997, Trautman et al. 1997, Shatsky et al. 1999). The question of whether the microcrystals and macrocrystals of diamond are related to different stages of formation of diamond, or if they represent a common population of diamond with crystal size depending on local conditions of growth, is still a matter of debate. A remarkable feature of microcrystals of diamond in the Arkhangelsk pipes in Russia is the high proportion of octahedral crystals (Zakharchenko et al. 1996). A comparison of macrocrystals and microcrystals from Australia and Yakutia reveals that the latter are also characterized by a greater-than-average proportion of octahedral crystals, as well as type-IIa crystals (Trautman et al. 1997). 
At present, the literature devoted to comparisons of impurities in diamond from different localities is scant. For the purposes of this investigation, we have analyzed IR spectra of several thousand diamond crystals, compiled and interpreted during the course of our studies of the Siberian (Yakutian), Arkhangelsk, Uralian, South African, Canadian, Venezuelan and Brazilian diamond fields during the period 1980s - 1990s. This study complements our previously published preliminary results on diamond crystals from these deposits (e.g., Blinova 1987, Blinova et al. 1985, 1989, 1991, Smirnov et al. 1986, Kaminsky et al. 2000, 2001).

\section{Analytical Methods}

IR absorption spectra of the diamond samples in our study were recorded using the Specord M-80 spectrophotometer (Carl Zeiss, Jena) with a beam condenser, operating within the spectral range of 4000 to $400 \mathrm{~cm}^{-1}$. Spectral resolution is $6-10 \mathrm{~cm}^{-1}$. In addition, some of the diamond crystals were analyzed at CSIRO, Sydney, Australia using a technique described by Davies et al. (1999). The relative error in the concentration of nitrogen appears to be \pm 10 to $20 \%$.

In those diamond crystals that only show individual IR absorption bands related to the A- and B-type defects, nitrogen concentrations are directly proportional to IR absorption coefficient values at the $1282 \mathrm{~cm}^{-1}$ spectral peak:

$$
\begin{aligned}
& \mathrm{N}_{\mathrm{A}}=\mathrm{K}_{\mathrm{A}} * \mu_{1282}=\left(16.5 \pm 1 \text { at.ppm } / \mathrm{cm}^{-1}\right) \mu_{1282} \\
& (\text { Boyd } \text { et al. } 1994) ;
\end{aligned}
$$

$$
\begin{aligned}
& \mathrm{N}_{\mathrm{B}}=\mathrm{K}_{\mathrm{B}} * \mu_{1282}=\left(79.4 \pm 8 \text { at.ppm } / \mathrm{cm}^{-1}\right) \mu_{1282} \\
& (\text { Boyd } \text { et al. } 1995) ;
\end{aligned}
$$

where $\mathrm{N}_{\mathrm{A}}$ and $\mathrm{N}_{\mathrm{B}}$ are concentrations of the $\mathrm{A}$ and $\mathrm{B}$ centers in at.ppm, respectively, $\mathrm{K}_{\mathrm{A}}$ and $\mathrm{K}_{\mathrm{B}}$ are coefficients for the A and B centers, respectively, and $\mu_{1282}$ is the intensity of the absorption peak at the frequency $1282 \mathrm{~cm}^{-1}$.

Most samples of natural diamond, however, belong to the combined Type IaAB, where the A and B defects occur together. In this case, in order to determine the concentrations of different nitrogen centers, we used a combination of the methods, proposed by Mendelssohn \& Milledge (1995), utilizing the diagrams presented by Meyer et al. (1997). All our data, including those published before 1995, were recalculated using this technique.

The relative proportions of the "platelets" $(\mathrm{P})$ and the hydrogen $(\mathrm{H})$ structural impurities in the diamond were estimated in this study in arbitrary units, more precisely, in terms of the absorption-coefficient values measured, respectively, at 1365 and $3107 \mathrm{~cm}^{-1}$. To our knowledge, no one has yet managed to measure a real concentration of nitrogen in diamond.

\section{SAMPLES ANALYZED}

We examined statistically and morphologically representative sets of diamond crystals from kimberlite pipes, sills and placers (30-200 samples from each locality). Among the crystals studied were diamond crystals from fifteen kimberlite pipes in the MaloBotuobinsk and Daldyn-Alakit areas in Yakutia, from the Arkhangelsk Province in Russia, from the Premier pipe in South Africa, from pipe DO-27 in the Slave Province, Canada, and from kimberlite sills in Guaniamo, Venezuela. In addition, placer diamond crystals from Yakutia, the Urals, Venezuela and Brazil (Minas Gerais and Mato Grosso states) were analyzed. In total, these comprise a collection of diamond samples spanning five continents (Table 1).

\section{RESULTS}

\section{Statistical differences in the concentration of impurity centers}

The results of our analysis are presented in Table 1. We report the average concentrations of structural defects in diamond, which may vary widely both within single deposits and regionally. In some zoned crystals of diamond from the Urals and Arkhangelsk, there were variations in the total nitrogen content in different zones from 140 to 1700 at.ppm (Blinova 1987, Zakharchenko et al. 1996). Even greater variations were recorded in the total nitrogen content between zones in single crystals from the Jagersfontein kimberlite, South Africa (Chinn et al. 1998): from 20 to 3250 at.ppm. In such zoned crystals, the nitrogen content in one of the zones is predominant. For all zoned crystals, the integral nitrogen content was measured.

It is not unusual to find more than one group of diamond crystals, with differing concentrations of optically active defects, in a collection from a particular deposit. When comparing suites of diamond from different deposits, one should use data on sets of crystals rather than single analyses. We illustrate this point with curves displaying the distribution of the A structural defect in diamond from the Pomorskaya and Karpinsky-1 pipes of the Arkhangelsk kimberlite province (Fig. 1). Two populations of diamond are distinguished in these pipes (as well as in all other pipes of the Arkhangelsk Province): (1) macrocrystals (+1 mm), and (2) microcrystals of diamond (-1 mm) (Zakharchenko et al. 1996). The macrocrystals are characterized by A-defect contents varying from 200 to 2500 at.ppm (Fig. 1). They have different modes, with the Karpinsky-1 crystals at approximately 500 at.ppm, and the Pomorskaya crystals at approximately 1300 at.ppm (Table 1). The microcrystals from both pipes are similar to each other in terms of their concentrations of A defects, but differ significantly from the macrocrystals in their generally lower concentration of A defects. The microcrystals 
contain from 10 to 700 at.ppm of the A defect, with a mode of approximately 250 at.ppm (Fig. 1). These statistical differences are clearly seen in the distribution curves, whereas in each set there are diamond crystals with 200-700 at.ppm of the A defect (Fig. 1).

\section{Variations in total concentration of the nitrogen impurity}

Regionally, from pipe to pipe and from one province to another, concentrations of structural defects in diamond vary even more than in the Arkhangelsk Province. As can be seen in Figure 2, the total concentration of nitrogen in diamond, $\mathrm{N}_{\mathrm{tot}}=\mathrm{N}_{\mathrm{A}}+\mathrm{N}_{\mathrm{B}}$, varies from close to zero to 1700 at.ppm depending of the provenance. In single crystals, we found $\mathrm{N}_{\text {tot }}$ values reaching as high as $2800 \mathrm{ppm}$; these values are similar to those reported by Meyer et al. (1997). For the statistical estimates in the text below and in figures, we used $\mathrm{N}_{\text {tot }}$ modal concentrations and a range from $-35 \%$ to $+35 \%$ of the mode value.

The diamond crystals studied can be subdivided on the basis of their total nitrogen content into three groups (Fig. 2). Group 1 consists of low-nitrogen diamond crystals with $\mathrm{N}_{\text {tot }}$ ranging from almost zero to 50 at.ppm. This group includes diamond from the Juina area in Brazil. It has minimal contents of nitrogen; by this criterion, the majority of the crystals are of type IIa (Kaminsky et al. 2001). Group 2 includes diamond

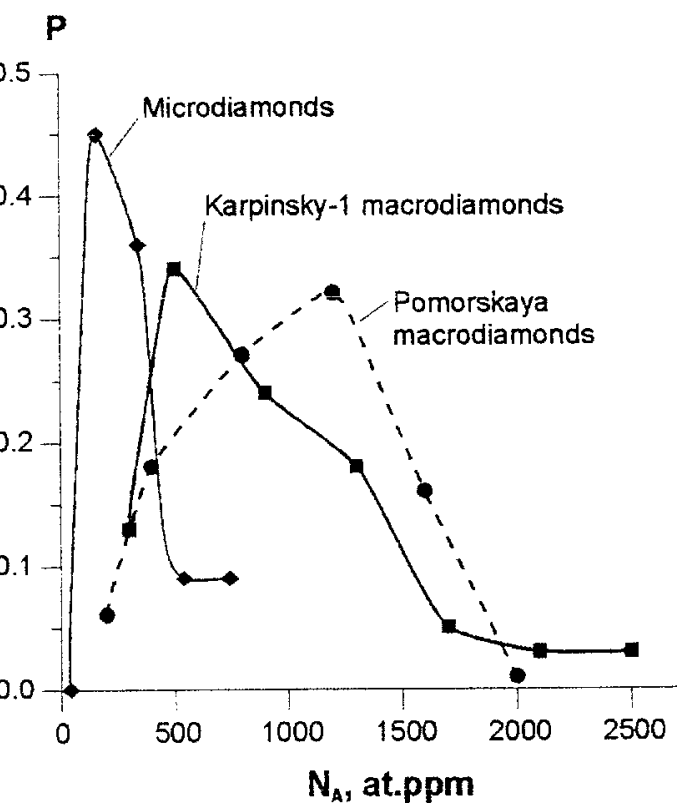

FIG. 1. Distribution of concentrations of A-type nitrogen impurity in diamond from the Pomorskaya and Karpinsky1 pipes, Arkhangelsk Province. TABLE 1. EVALUATION OF OPTICALLY ACTIVE DEFECTS
IN DIAMOND FROM VARIOUS AREAS

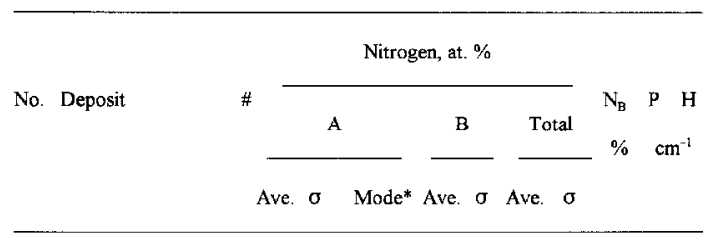

Pipes of the Malo-Botuobinsk area, Yakutia, Russia

1 International

2 Sputnik

3 XXIII Congress of CPSU

$\begin{array}{lllllllllll}57 & 626 & 336 & 590 & 181 & 89 & 807 & 386 & 22 & 3.4 & 1.0\end{array}$

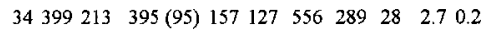

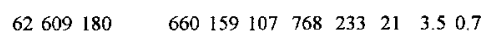

Pipes of the Daldyn-Alakit area, Yakutia, Russia

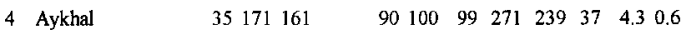

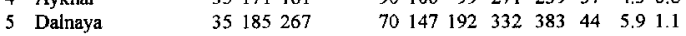

6 Komsomolskaya $\quad 39315267 \quad 165180176 \quad 495 \quad 380 \quad 3610.80 .9$

$\begin{array}{lllllllllllll}7 & \text { Krasnopresnenskaya } 43 & 291 & 275 & 110 & 192 & 140 & 483 & 341 & 40 & 7.6 & 1.7\end{array}$

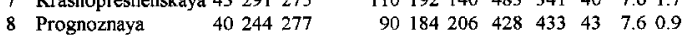

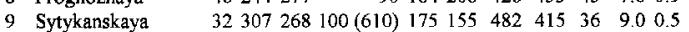

10 Udachnaya $\quad 39295242110(560) \quad 133 \quad 94 \quad 428 \quad 302 \quad 31 \quad 4.2 \quad 1.3$

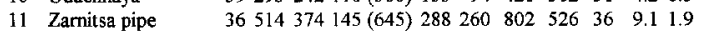

\section{Northeastern Yakutia, Russia}

12 Triassic placers $\quad 43640 \quad 425 \quad 4254092131049 \quad 550 \quad 39 \quad 7.30 .6$

Pipes of the Arkhangelsk Province, Russia

\begin{tabular}{|c|c|c|c|}
\hline Arkhangelskaya & 39966363 & $326248 \quad 1292 \quad 431$ & 2525.32 .9 \\
\hline Karpinsky-1 & 77698646 & $300221998 \quad 475$ & $\begin{array}{lll}30 & 6.1 & 3.4\end{array}$ \\
\hline Lomonosov & $102625507 \quad 140(645)$ & $202205827 \quad 600$ & 2419.82 .1 \\
\hline Pomorskaya & $159939472 \quad 1300$ & 3563311295656 & $28 \quad 6.5 \quad 3.9$ \\
\hline
\end{tabular}

16 Pomorskaya $\quad 159939472 \quad 13003563311295 \quad 656 \quad 28 \quad 6.53 .9$

\section{Placers of the Urals, Russia}

17 Middle Urals placers 55548340925 (175) $264 \quad 175 \quad 812 \quad 380 \quad 33 \quad 8.00 .6$

\section{South Africa}

18 Premier pipe $\quad 19262227 \quad 100205173 \quad 467 \quad 343 \quad 44 \quad 10.0$ n.d.

Slave Province, Canada

19 Pipe DO-27 $201363261 \quad 110(430) 214 \quad 179 \quad 576 \quad 250 \quad 37 \quad 4.61 .3$

Placers from Coromandel, Minas Gerais, Brazil

20 Grota do Pimpim $34234 \quad 155 \quad 230277 \quad 163 \quad 508 \quad 266 \quad 54 \quad 6.30 .6$

21 Cor Sto.Antonio-

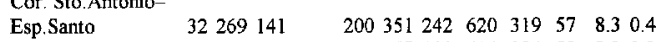

22 Cor Imbe

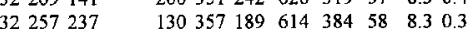

23 Cor. Criminosa $\quad 32206127 \quad 240(85) 280176 \quad 486 \quad 290 \quad 58 \quad 5.50 .8$

Placers from Juina, Mato Grosso, Brazil

\begin{tabular}{|c|c|c|c|c|c|c|c|c|c|c|}
\hline 24 & Rio Sao Luis & 31 & 12 & 10 & 78 & 87 & 83 & 93 & 95 & 0.20 .2 \\
\hline 25 & Rio Vermelho & 33 & 14 & 10 & 88 & 97 & 93 & 73 & 95 & 0.40 .2 \\
\hline 26 & Cor. Chicora & 34 & 19 & 10 & 74 & 49 & 81 & 57 & 91 & 0.30 .2 \\
\hline \multicolumn{11}{|c|}{ Placers from Venezuela } \\
\hline 27 & Kimberlite sills & 51197 & 110 & 120 & 417 & 252 & 614 & 310 & 68 & 9.71 .0 \\
\hline 28 & Quebrada Grande & 40226 & 114 & 150 & 480 & 251 & 706 & 352 & 68 & 12.31 .3 \\
\hline 29 & Guaniamito & 52251 & 120 & 145 & 468 & 245 & 719 & 312 & 65 & 12.00 .7 \\
\hline 30 & Chihuahua & 33220 & 128 & 115 & 463 & 193 & 683 & 255 & 68 & 13.10 .6 \\
\hline 31 & Ringi-Ringi & 33220 & 113 & 175 & 485 & 260 & 705 & 292 & 69 & 12.30 .6 \\
\hline 32 & La Centella & 40174 & 78 & 125 & 349 & 201 & 523 & 251 & 67 & 8.90 .9 \\
\hline
\end{tabular}

* Additional mode is shown in brackets. 
samples from the majority of the deposits studied, including the Yakutian pipes, deposits of the Guaniamo area (Venezuela) and the Coromandel area (Brazil), with total concentrations of the nitrogen structural impurity varying between 50 and 1000 at.ppm. Although nitrogen concentrations in diamond from the different localities generally differ, the respective ranges of concentration do overlap, and there are transitions between them (Fig. 2). Two subgroups may be distinguished among these samples. Group 2a has total concentrations of the nitrogen structural impurity from 50 to 400 at.ppm, and includes diamond from the Premier mine (South Africa), diamond crystals from the Daldyn-Alakit kimberlite pipes in Yakutia, and some Arkhangelsk crystals. Group $2 \mathrm{~b}$, with a relatively higher total nitrogen content (4001000 at.ppm), includes diamond crystals from the MaloBotuobinsk pipes in Yakutia and the most of South American crystals. Group 3 are high-nitrogen diamond crystals from the Arkhangelskaya and Pomorskaya pipes of the Arkhangelsk Province, which contain between 1000 and 1700 at.ppm of nitrogen.

In general, each region is characterized by diamond crystals of one particular group. However, the Arkhangelsk kimberlite province is an exception. Dia-

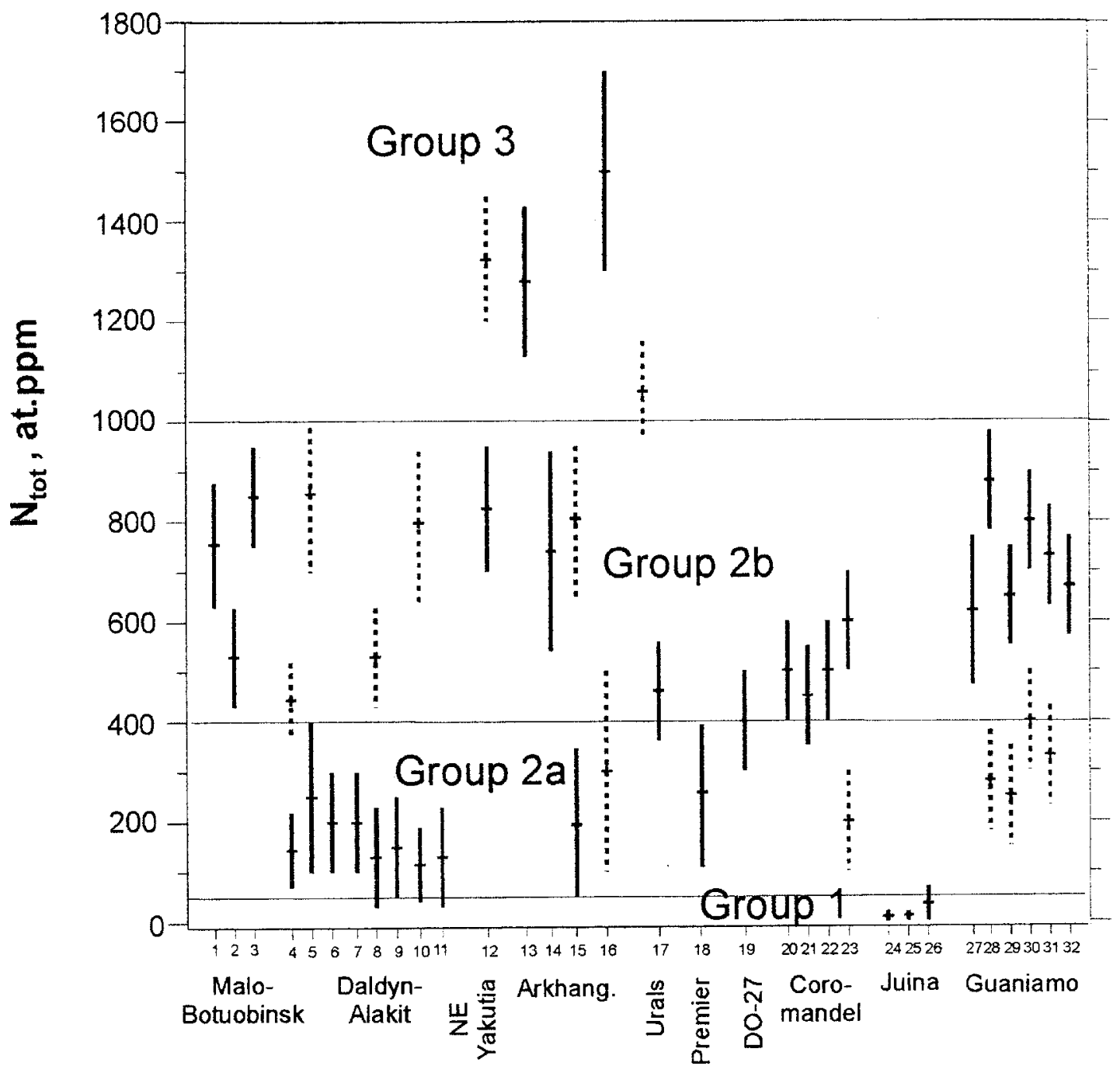

FIG. 2. Ranges of variation in the content of structurally bound nitrogen (modes of $\mathrm{N}_{\text {tot }}=\mathrm{N}_{\mathrm{A}}+\mathrm{N}_{\mathrm{B}}$, at.ppm) in diamond crystals from different areas. Concentration ranges of $\mathrm{N}_{\text {tot }}$ are shown from $-35 \%$ to $+35 \%$ of the mode value: solid lines: main modes, dotted lines: additional modes. Mode values are shown by short lines. Numbers correspond to the area numbers in Table 1. 
mond crystals from this area belong to two groups. Diamond crystals from the Lomonosov pipe are predominantly group-2a crystals, with $\mathrm{N}_{\text {tot }}$ in the range 20 420 at.ppm, whereas diamond crystals from the Karpinsky-1 pipe belong to group $2 b$, and all diamond crystals from the Arkhangelskaya and Pomorskaya pipes are high-nitrogen group-3 stones (Table 1, Fig. 2).

Some localities (both kimberlites and placer deposits) are characterized by more than a single mode in the distribution of $\mathrm{N}_{\text {tot }}$ value in diamond; they have a major mode and an additional one. This points to the existence of a number of distinct populations in the deposit.

\section{Variations of nitrogen content in A form}

In some cases, the characteristic features of diamond crystals may be better observed in $\mathrm{N}_{\mathrm{A}}$ than in $\mathrm{N}_{\text {tot }}$. The $\mathrm{N}_{\mathrm{A}}$ concentration in diamond is obviously lower than $\mathrm{N}_{\text {tot }}$. Among the localities considered, it varies from almost zero to 1500 at.ppm (Fig. 3). As with $\mathrm{N}_{\text {tot }}$ values, we used the mode values for construction of Figure 3. In some areas, two modes were observed (Table 1).

Figure 3 demonstrates, in general, the same regularities in the distribution of $\mathrm{N}_{\mathrm{A}}$ in diamond as Figure 2 does for $\mathrm{N}_{\text {tot }}$. Three groups of diamond crystals can thus be distinguished: low-nitrogen ( $0-20$ at.ppm $\mathrm{N}_{\mathrm{A}}$ ), medium-nitrogen (20-800 at.ppm, with two subgroups, 20300 at.ppm and 300-800 at.ppm), and high-nitrogen (800-1500 at.ppm). Some of the diamond suites occupy different positions in Figures 2 and 3. For example, diamond from the Coromandel area, Brazil, and those from Guaniamo, Venezuela, plot as group 2a in Figure 3, whereas they fall into the high to medium group $2 b$ in terms of total nitrogen content (Fig. 2). This reflects a significantly higher degree of aggregation of nitrogen impurity in the diamond crystals of the Coromandel and Guaniamo (see below).

\section{Other defect centers}

"Platelets" $(\mathrm{P})$ and hydrogen $(\mathrm{H})$ centers, like the nitrogen defects, are important indicators of the conditions of formation. In many kimberlite deposits, cubic crystals of diamond with columnar internal structures, reflecting the normal mechanism of crystal growth, occur. These crystals are characterized by a hydrogen content greater than that of octahedral crystals of diamond; as a rule, no $\mathrm{P}$ centers are detected in cubic crystals of this sort (Plotnikova \& Klyuev 1986, Blinova 1987). It is noteworthy that crystals subject to normal crystalgrowth are not necessarily cubic in shape because at the final stage of their formation, these crystals may be subject to dissolution or to a change in their growth mechanism (Zakharchenko et al. 1996).

Variations in the concentration of $\mathrm{P}$ and $\mathrm{H}$ centers in diamond in comparison to their mode of nitrogen aggregation are shown in Figures 4 and 5. Diamond from the Arkhangelsk kimberlite province differs from dia- mond from the other regions included in this study by their higher-than-average content of hydrogen impurity. The Juina diamond crystals have the lowest concentrations of "platelets".

\section{Nitrogen aggregation in diamond from different areas}

Figures 4 and 5 display the relationships between the average concentrations of $\mathrm{P}$ and $\mathrm{H}$ centers and the proportion of aggregated nitrogen $\left[\% \mathrm{~N}_{\mathrm{B}}=100 \mathrm{~N}_{\mathrm{B}} /\left(\mathrm{N}_{\mathrm{A}}+\right.\right.$ $\mathrm{N}_{B}$ )]. These diagrams allow discrimination between diamond crystals both from provinces and different areas within a common province. Diamond crystals from pipes of the Daldyn-Alakit area differ from those of the Malo-Botuobinsk area in Yakutia by their higher relative proportions of aggregated nitrogen $\left(\% \mathrm{~N}_{\mathrm{B}}\right)$ and $\mathrm{P}$ centers. The characteristic feature of South American diamond crystals, from the Juina area, Brazil, is their higher-than-average proportion of $\mathrm{N}_{\mathrm{B}}$, reaching up to almost $100 \%$ nitrogen aggregation.

Diamond from the deposits included in this study were divided into the following three groups, based on proportion of aggregated nitrogen in their total content of nitrogen impurity. Group 1, with a maximum proportion (up to almost 100\%) of aggregated nitrogen, includes diamond crystals from the Juina area. Group 2, with a proportion of aggregated nitrogen intermediate between those of groups 1 and $3(35-75 \%)$, includes diamond crystals from the Daldyn-Alakit area in Yakutia and from Coromandel and the Guaniamo placers. Group 3, with a low relative proportion of aggregated nitrogen (less than 35\%), includes diamond crystals from the Malo-Botuobinsk area in Yakutia and from the Arkhangelsk kimberlite province.

In general, these groups correlate with the groups distinguished on the basis of nitrogen content (Figs. 2, 3 ). Diamond crystals with a high proportion of aggregated nitrogen have the lowest total nitrogen content, whereas those that are low in aggregated nitrogen are generally rich in total nitrogen. The main differences are present in the Yakutian crystals. Crystals from the Malo-Botuobinsk area, being moderate in their total nitrogen content, seem to be the lowest in aggregated nirogen.

\section{DISCUSSION}

\section{Estimation of temperature of formation of diamond from different areas}

The distinctions in distributions of the nitrogen impurity in diamond from different deposits, areas and regions reflect dissimilar conditions of crystallization and post-crystallization thermal histories. The calculations performed on the basis of experimental data on transformations of nitrogen defects under high temperatures and high pressures, reveal that the degree of nitrogen aggregation in diamond depends on temperature, 
total content of nitrogen impurity, and the duration of thermal action (e.g., Evans 1992, Taylor et al. 1996). On the basis of calculations, a set of diagrams was constructed by Taylor et al. (1990), Taylor \& Milledge (1995) and Trautman et al. (1997) in order to estimate the probable range of temperature of diamond formation, with a given "residence time in the mantle", and the probable age of the diamond-formation process with known thermal parameters. We used a modified version of the diagram used by Taylor \& Milledge (1995) to estimate the temperature of formation of the diamond crystals studied, assuming an average age of $3 \mathrm{Ga}$ (Fig. 6).

According to our estimates, the highest temperatures of formation $\left(1250^{\circ} \mathrm{C}\right)$ are characteristic of the diamond crystals from the Juina area. This coincides with a pro-

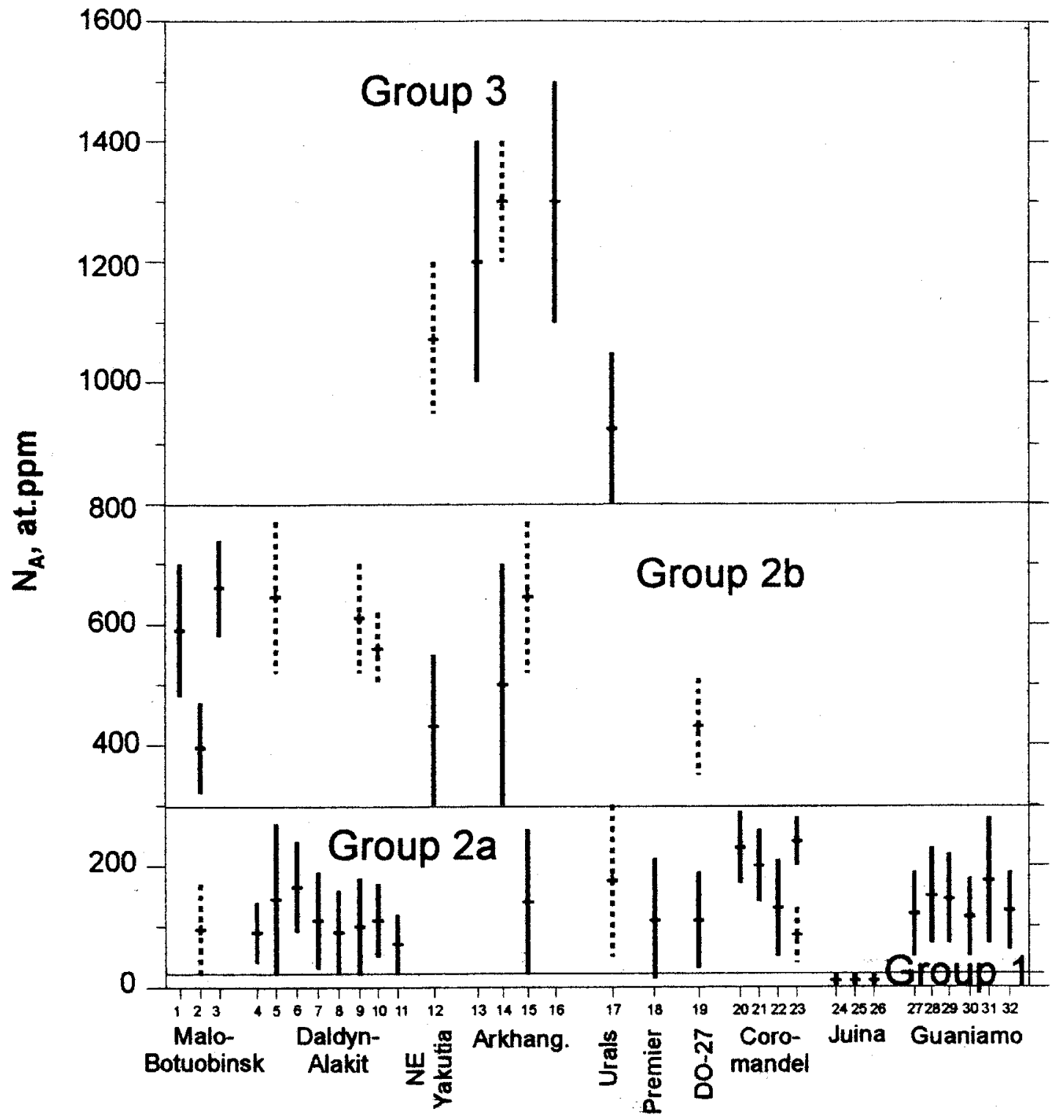

FIG. 3. Ranges of variation of nitrogen content in A-type nitrogen impurity (modes of $\mathrm{N}_{\mathrm{A}}$, at.ppm) in diamond from different areas. Concentration ranges of $\mathrm{N}_{\mathrm{A}}$ are shown from $-35 \%$ to $+35 \%$ of the mode value: solid lines: main modes, dotted lines: additional modes. Mode values are shown by short lines. Numbers correspond to the area numbers in Table 1 and Figure 2. 


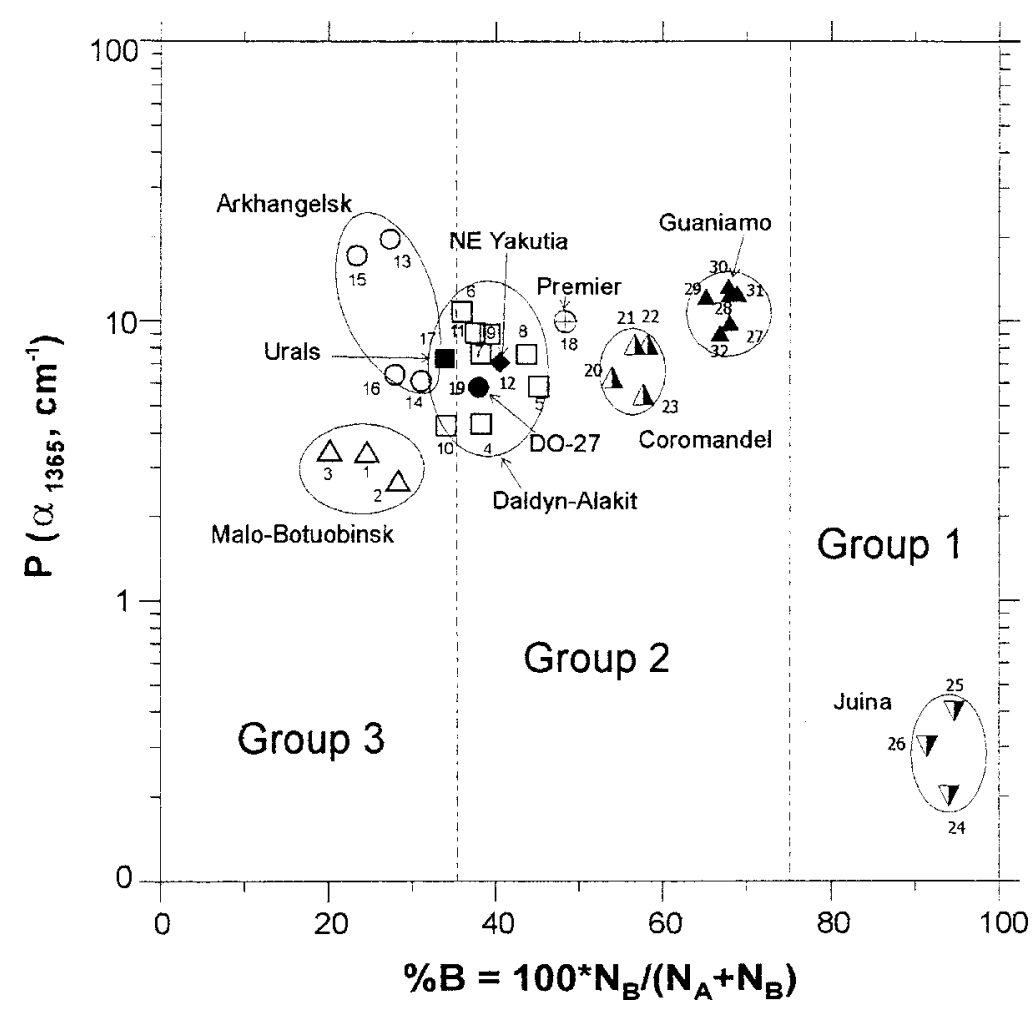

FIG. 4. Distribution of "platelets" $(P)$ and proportion of aggregated nitrogen $\left[\% \mathrm{~N}_{B}=\right.$ $100 * \mathrm{~N}_{B} /\left(\mathrm{N}_{\mathrm{A}}+\mathrm{N}_{\mathrm{B}}\right)$ ] in diamond from different regions. $\mathrm{P}$ is an average "platelet" content in diamond in arbitrary units as a function of the absorption coefficient value measured at $1365 \mathrm{~cm}^{-1}$. Numbers shown in different areas correspond to the numbers in Table 1.

posed origin within the lower mantle for these diamond crystals (Kaminsky et al. 2001). The general temperature of formation for diamond crystals from the DaldynAlakit area in Yakutia and from the Coromandel and Guaniamo areas is between 1100 and $1150^{\circ} \mathrm{C}$. However, the temperature for the Guaniamo crystals may be underestimated, because the majority of these crystals belong to the eclogitic association (Kaminsky et al. 2000), which may suggest an age that is younger than $3 \mathrm{Ga}$ (according to the Taylor-Milledge diagram, the shorter the duration of thermal action, the higher the temperature). In this case, the Guaniamo crystals may have formed at a temperature $c a .1170^{\circ} \mathrm{C}$. The lowest temperatures of formation are associated with the deposits of the Malo-Botuobinsk area in Yakutia and the pipes of the Arkhangelsk kimberlite province; they vary between 1075 and $1100^{\circ} \mathrm{C}$. The temperature of crystallization of diamond from the Arkhangelsk Province also may be underestimated, owing to the fact that diamond from this region formed essentially through the normal mechanism of growth, which suggests relatively rapid crystallization under the conditions of oversaturation and high temperature-gradients. This hypothesis may also apply to diamond crystals from the MaloBotuobinsk area, as many of these show cube-octahedral central growth-zones. Temperature estimates vary within diamond from a single area or deposit, although there is some overlap. This fact, together with the varying character of the distribution of structural defects, point to a discontinuous, multistage process of formation.

One should understand that the calculated values of temperature are approximations based on the assumption that diamond formation occurred at $3 \mathrm{Ga}$ ago. The real temperatures may be different, as has been demonstrated above for some areas (Guaniamo and the Arkhangelsk Province). We propose that in the Juina area, the temperature of formation of diamond was significantly higher than the calculated $1250^{\circ} \mathrm{C}$, because the mantle adiabat at a depth of $660 \mathrm{~km}$ is thought to be at $1650^{\circ} \mathrm{C}$ (Ito \& Katsura 1989). The diamond crystals from Juina thus are likely to be significantly younger than $3 \mathrm{Ga}$. Development and application of new mineralogical geothermometers for super-deep mineral 


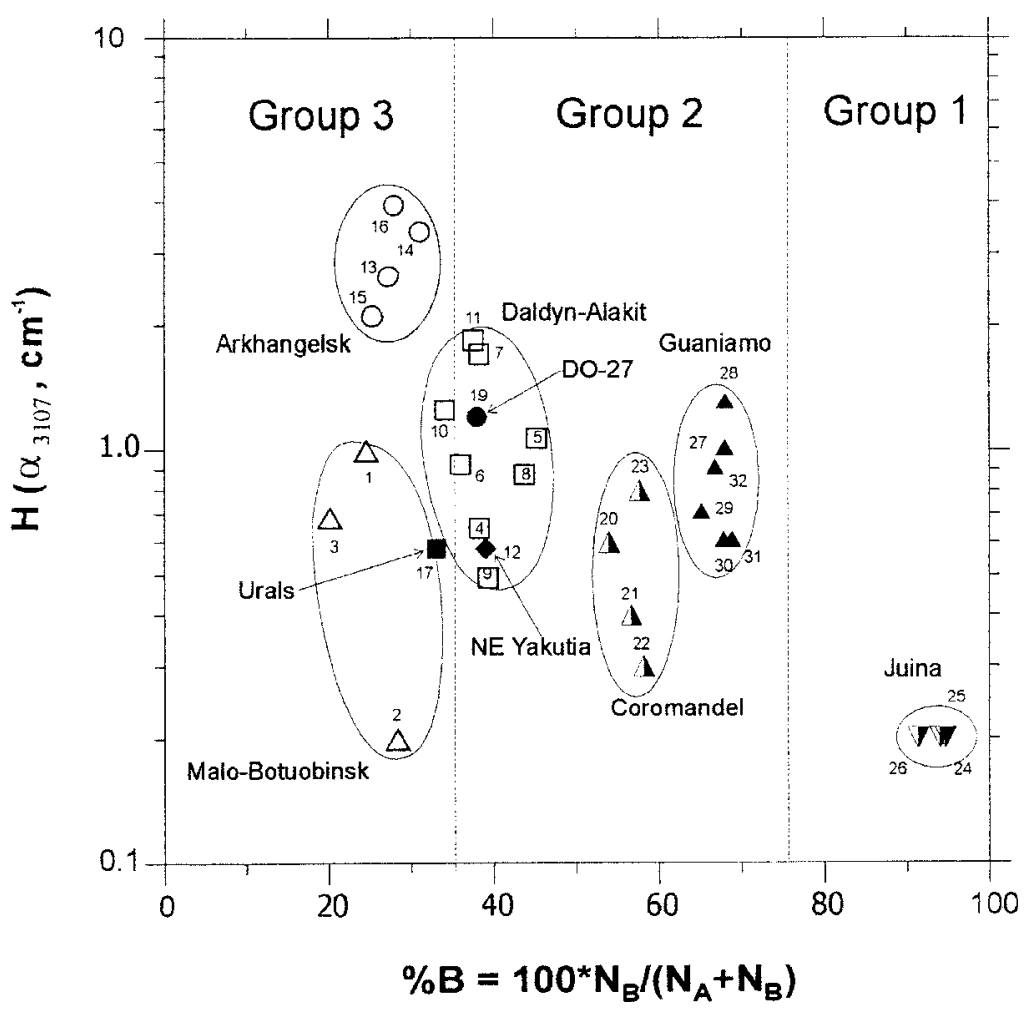

FIG. 5. Distribution of hydrogen $(\mathrm{H})$ and proportion of aggregated nitrogen $\left(\% \mathrm{~N}_{\mathrm{B}}\right)$ in diamond from different regions. $\mathrm{H}$ is an average hydrogen content in diamond in arbitrary units as a function of the value of the absorption coefficient measured at 3107 $\mathrm{cm}^{-1}$. Numbers shown in different areas correspond to the numbers in Table 1 and Figure 4.

associations will be of great assistance in future studies of diamond.

\section{Nitrogen impurity in diamond and stages of formation}

The multistage formation of natural diamond was established on the basis of zonal textures in birefringence, ultraviolet absorption, X-ray topographic and cathodoluminescence studies (e.g., Tolansky 1955, Orlov 1963, Takagi \& Lang 1964, Gurkina \& Miuskov 1971, Lang 1974, Milledge et al. 1989). Recently, several generations of diamond were distinguished among crystals recovered in some kimberlite pipes (e.g., Bulanova et al. 1999, Spetsius 1999).

On the basis of these data and the distribution of nitrogen-impurity centers in the crystals studied, three main stages are generally distinguished in the process of formation of diamond in nature. The diamond crystals related to these stages differ in the character and distribution of their structural defects and in the relative proportions of the different species of defects.
In the early stage, diamond formation proceeded at a maximum depth, in some cases, as deep as the lower mantle or transition zone. The set of super-deep mineral inclusions comprises ferroan periclase, perovskitegroup phases, native iron, nickel, majorite and other minerals formed at super-high pressure and temperature (Harte et al. 1999, Kaminsky et al. 2001). Diamond crystals of the early stage are commonly nitrogen-free (type IIa).

During the main stage, diamond formation proceeded in the upper mantle, and produced diamond associated with ultramafic and eclogitic parageneses. Nitrogen-free diamond crystals are less common here, all of them being genetically related to the ultramafic paragenesis. Diamond crystals from ultramafic xenoliths, as well as diamond crystals with mineral inclusions of ultramafic paragenesis, are in part of type IIa and in part low-nitrogen crystals. Diamond crystals of the eclogitic paragenesis are usually richer in nitrogen than "peridotitic" diamond. Most of the diamond crystals related to the main stage of diamond formation 


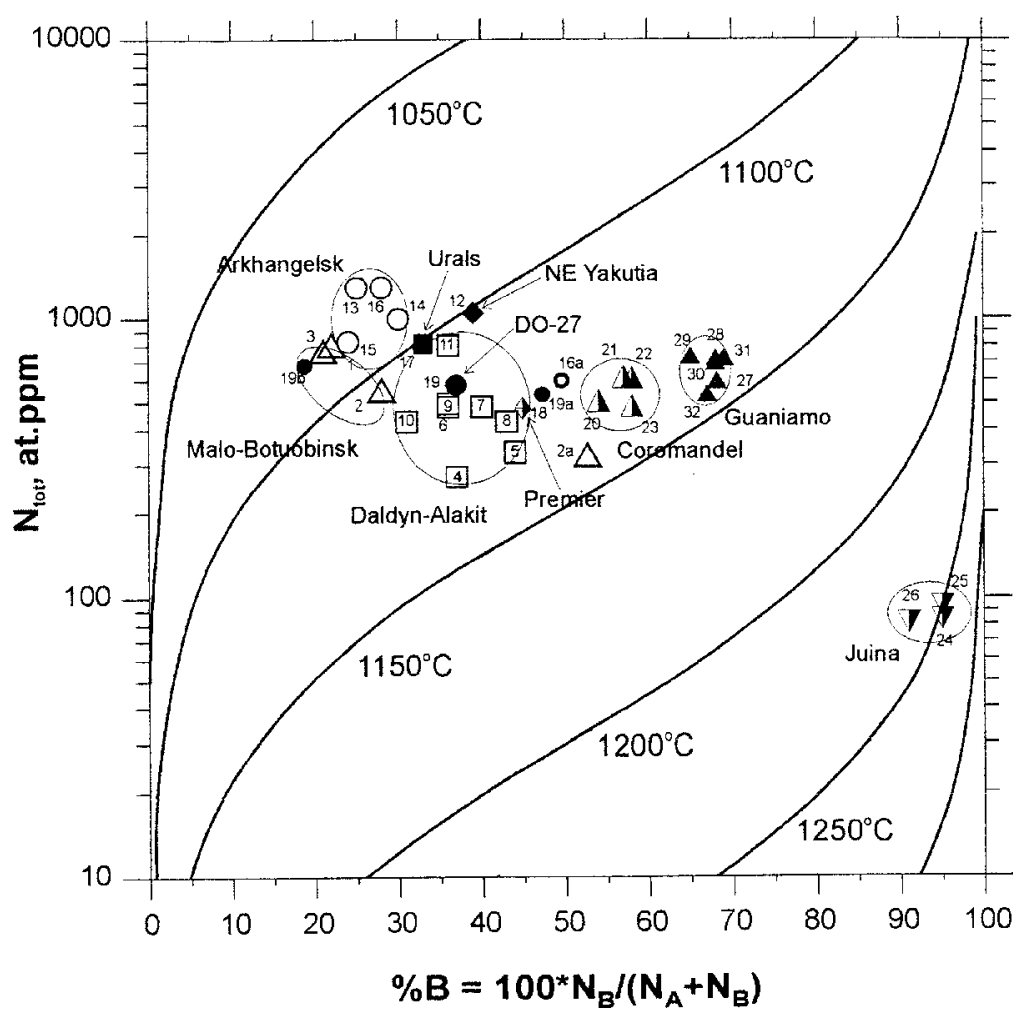

FIG. 6. Temperature estimates for diamond from different areas. Isotherm curves for $3 \mathrm{Ga}$ after Taylor \& Milledge (1995). Numbers correspond to the numbers in Table 1; others are: $2 \mathrm{a}$ : diamond crystals of ultramafic suite from the Sputnik pipe, 16a: microcrystalline diamond from the Pomorskaya pipe, 19a and 19b: diamond crystals of the first and second populations from the DO-27 pipe.

have total concentrations of nitrogen impurity varying between 50 and 1000 at.ppm (Fig. 2). In this respect, we highlight two subgroups of diamond with mineral inclusions of eclogitic paragenesis from the Roberts Victor pipe (Harris \& Spear 1986) and from the Jwaneng pipe (Cartigny et al. 1998). These diamond crystals were subdivided into two groups on the basis of their nitrogen content: (a) type-IIa diamond crystals and crystals close to them (i.e., those with less than 150 at.ppm nitrogen contents), and (b) diamond crystals with total nitrogen contents varying between 150 and 450 at.ppm.

The final stage of diamond formation evidently immediately preceded the emplacement of the kimberlitic magmas. The normal mechanism of growth, which is typical of diamond related to this stage, suggests high oversaturation of the crystallization medium and high internal temperature-gradients. Therefore, mineral chemistry of the inclusions captured by the diamond in the course of their fast growth may reflect a wide range of temperatures, probably beginning from temperatures of the upper mantle typical early on, followed by rapidly reducing temperatures, reflecting cooling. This is made clear by the eclogitic paragenesis of mineral inclusions in cubic crystals of diamond with normal growth and by the abundance of cubic crystals in kyanite-bearing eclogitic xenoliths (Bulanova et al. 1993). Most of the diamond crystals related to this stage of growth have high total concentrations of nitrogen defects (>1000 at.ppm; Fig. 2), whereas the relative proportion of aggregated nitrogen $\left(\% \mathrm{~N}_{\mathrm{B}}\right)$ in these crystals is low (as a rule, less than $35 \%$ ).

The bulk of known diamond crystals from a kimberlitic host-rock are related to the main stage of diamond formation. However, there are some deposits with a predominance of diamond crystals related to the early stage (such as the unique deposit of the Juina area, Brazil), and deposits with a considerable proportion of diamond crystals related to the final stage (e.g., the pipes of the Arkhangelskaya and Pomorskaya fields in the Arkhangelsk kimberlite province). In some diamond 


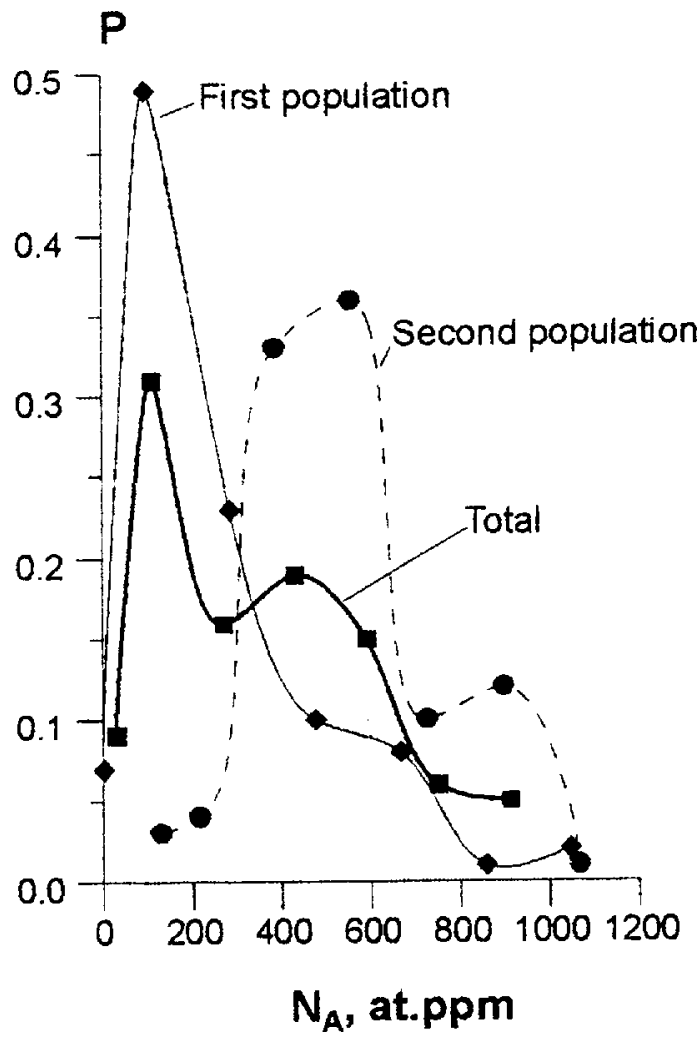

FIG. 7. Distribution of concentrations of A-type nitrogen impurity in diamond from pipe DO-27, Slave Province, Canada.

deposits, all three diamond groups may be observed, implying that diamond crystals have been formed in a given deposit in several stages.

As an example of multiple groups of diamond in a single deposit, let us consider the Pomorskaya pipe, Arkhangelsk Province. As mentioned above, this pipe contains both microcrystals and macrocrystals of diamond (Fig. 1). Assuming that they both have had the same residence time ( $3 \mathrm{Ga}$ ) under high-P, high-T conditions (from the Taylor-Milledge diagram), it follows that the average temperature of crystallization of microcrystals of diamond should be approximately $40-50^{\circ} \mathrm{C}$ higher than that of the macrocrystals (Fig. 6). The main stage of diamond formation, judging by the small size of the diamond crystals, thus was briefer than the final stage; the latter process seems to be dominant in the crystallization of diamond crystals from the Pomorskaya pipe.

Among the diamond crystals from the MaloBotuobinsk area, crystals with mineral inclusions of the ultramafic suite show lower than usual concentrations of nitrogen A-type defects (Bilenko 1982). According to our data, diamond crystals in ultramafic inclusions from the Sputnik pipe, Malo-Botuobinsk area, have double the aggregation ratio $(\% \mathrm{~B})$, compared to the rest of the diamond crystals (55 versus 28 , Fig. 6). The Sputnik diamond crystals within ultramafic inclusions thus formed at higher temperatures $\left(1140^{\circ} \mathrm{C}\right.$ at $\left.3 \mathrm{Ga}\right)$, compared to the remainder of the crystals $\left(1100^{\circ} \mathrm{C}\right.$ at $3 \mathrm{Ga}$, Fig. 6). It is likely that both high- and low-temperature crystals appeared during the main stage of diamond formation. Both populations are predominantly octahedral crystals with a tangential mechanism of growth.

Two populations of diamond have been identified, based on the IR absorption data, from pipe DO-27 in the Lac-de-Gras area, Slave Province, Canada. They exhibit a number of significant distinctions (Fig. 7). Diamond crystals of the first population are low in nitrogen; they form a continuous series with nitrogen-free type-IIa diamond crystals, which comprises approximately $5 \%$ of the diamond crystals in pipe DO-27. Diamond crystals of the second population differ from the first by having an above-average total nitrogen content and a lack of "platelets". According to their morphology, they are likely to have formed through the normal mechanism of growth. An estimation of crystallization time and temperature yielded $1130^{\circ} \mathrm{C}$ at $3 \mathrm{Ga}$ for lownitrogen diamond of the first population, and $1080^{\circ} \mathrm{C}$ at $3 \mathrm{Ga}$ for diamond of the second population (Fig. 6). On this basis, diamond crystals of the first population can be related to the main stage, and those of the second population, to the final stage of diamond formation. In addition to the two populations, there is probably a third one, the earliest stage, in pipe DO-27, as is evident in the minor proportion of nitrogen-free crystals with mineral inclusions of the super-deep paragenesis (Davies $e t$ al. 1999). As such, we can assume the presence of all three diamond groups in pipe DO-27, representing the three main stages of their formation.

The data obtained in this study may be used for "fingerprinting" purposes, in prospecting for new deposits in diamondiferous areas, and in the evaluation of diamond crystals from newly discovered deposits.

\section{ACKNOWLEDGEMENTS}

We thank Guaniamo Mining Co., Canabrava Diamond Corp., Diagem International Resource Corp., Dentonia Resources Ltd., Kennecott Canada Exploration Inc., and J.B. Hawthorne for the samples submitted for the IR analysis, and for the partial financial support of this study. Ian Coulson helped us in editing the text. We are grateful to Dante Canil and Robert F. Martin for thoughtful and constructive reviews, which improved the manuscript. 


\section{REFERENCES}

BILENKo, Yu.M. (1982): Nitrogen content in diamonds of primary deposits in Yakutia. Sov. Geol. Geophys. 23(7), 117119.

BLINOVA, G.K. (1987): Structural impurities as indicators of the mechanism of natural diamond growth. Sov. Phys. Dokl. 36(6), 425-426.

, Botkunov, A.I., Kaminskit, F.V., Koshchug, D.G. \& Frolova, L.N. (1985): Distinctive features of the distribution of nitrogen centers in diamonds from a pair of kimberlite pipes of Yakutia. Sov. Geol. Geophys. 26(3), 111-114.

Ilupin, I.P., Gurkina, G.A. \& Frolova, L.N (1991): Impurity centers in diamonds from two regions of Siberian platform. Sov. Geol. Geophys. 32(8), 76-78.

, VerZHAK, V.V., ZAKHARChENKO, O.D., MEDVEDEVA, M.S. \& Sobolev, E.V. (1989): Impurity centers in diamonds from two kimberlite pipes of the Arkhangel diamond province. Sov. Geol. Geophys. 30(8), 122-125.

Boyd, S.R., Kiflawi, I. \& Woods, G.S. (1994): The relationship between infrared absorption and A-defect concentration in diamond. Phil. Mag. B69, 1149-1153.

$\&$ (1995): Infrared absorption by the B nitrogen aggregate in diamond. Phil. Mag. B72, 351-361.

Bulanova, G.P., Barashiov, Yu.P., Talnikova, S.B. \& Smelova, G.B. (1993): Natural Diamond: Genetic Aspects. Nauka Press, Novosibirsk, Russia (in Russ.).

, Shelkov, D., Milledge, H.J., Hauri, E.H. \& SMith, C.B. (1999): Nature of eclogitic diamonds from Yakutian kimberlites: evidence from isotopic composition and chemistry of inclusions. In Proc. VIIth Int. Kimberlite Conf., 1 (J.J. Gurney, J.L. Gurney, M.D. Pascoe \& S.H. Richardson, eds.). Red Roof Design, Cape Town, South Africa (57-65).

Bursill, L.A. \& Glaisher, R.W. (1985): Aggregation and dissolution of small and extended defect structures in type Ia diamond. Am. Mineral. 70, 608-618.

CARTigny, P., Harris, J.W. \& Javoy, M. (1998): Eclogitic diamond formation of Jwaneng: no room for a recycled component. Science 280(5368), 1421-1424.

Chinn, I.T., Milledge, H.J. \& GuRney, J.J. (1998): Diamond and inclusions from the Jagersfontein kimberlite. In Seventh Int. Kimberlite Conf. (Cape Town), Extended Abstr., 156-157.

DAVIES, G. (1976): The A nitrogen aggregate in diamond - its symmetry and possible structure. J. Phys. C9, L537-L542.

Davies, R., Griffin, W.L., Pearson, N.J., Andrew, A., DoYle, B.J. \& O'ReILly, S.Y. (1999): Diamonds from the deep: Pipe DO-27, Slave Craton, Canada. In Proc. Seventh
Int. Kimberlite Conf. 1 (J.J. Gurney, J.L. Gurney, M.D. Pascoe \& S.H. Richardson, eds.). Red Roof Design, Cape Town, South Africa (148-155).

Evans, T. (1992): Aggregation of nitrogen in diamond. In The Properties of Natural and Synthetic Diamond (J. Field, ed.). Academic Press, London, U.K. (259-290).

GuRkinA, G.A. \& Miuskov, V.F. (1971): Study of internal morphology of natural diamonds by X-ray topographic method. Almazi (Diamonds) 11, 1-4 (in Russ.).

Harris, J.W. \& Spear, P.M. (1986): Systematic studies of nitrogen in diamonds from known sources. In Fourth Int. Kimberlite Conf. (Perth), Abstr., 398-400.

Harte, B., Harris, J.W., Hutchison, M.T., Watt, G.R. \& WILDING, M.C. (1999): Lower mantle mineral associations in diamonds from Sao Luiz, Brazil. In Mantle Petrology: Field Observations and High Pressure Experimentation: A Tribute to Francis R (Joe) Boyd (Y. Fei, C.M. Bertka \& B.O. Mysen, eds.). Geochem. Soc., Spec. Publ. 6, 125-153.

Hutchison, M.T., Cartigny, P. \& Harris, J.W. (1999): Carbon and nitrogen compositions and physical characteristics of transition zone and lower mantle diamonds from Sao Luiz, Brazil. In Proc. Seventh Int. Kimberlite Conf. 1 (J.J. Gurney, J.L. Gurney, M.D. Pascoe \& S.H. Richardson, eds.). Red Roof Design, Cape Town, South Africa (372-382).

Ito, E. \& Katsura, T. (1989): A temperature profile on the mantle transition zone. Geophys. Res. Lett. 16, 425-428.

KAMINSKy, F.V., ZAKHARChENKo, O.D., DAVIES, R., GrifFin, W.L., Khachatryan-Blinova, G.K. \& Shiryaev, A.A. (2001): Super-deep diamonds from the Juina area, Mato Grosso State, Brazil. Contrib. Mineral. Petrol. 140, 734753.

Griffin, W.L., Channer, D.M.DeR. \& Khachatryan-Blinova, G.K. (2000): Diamond from the Guaniamo area, Venezuela. Can. Mineral. 38, 1347-1370.

LANG, A.R. (1974): On the growth-sectorial dependence of defects in natural diamonds. Proc. Roy. Soc. London A340(1621), 233-248.

LEAHY, K. \& TAYLOR, W.R. (1997): The influence of the Glennie domain deep structure on the diamonds in Saskatchewan kimberlites. Russ. Geol. Geophys. 38, 481491.

Lee, D.C., Milledge, H.J., Reddicliffe, T.H., Scott Smith, B.H., TAYLOR, W.R. \& WARD, L.M. (1995): The Merlin kimberlites, Northern Territory, Australia. In Sixth Int. Kimberlite Conf. (Novosibirsk), Extended Abstr., 317-319.

Mendelssohn, M.J. \& Milledge, H.J. (1995): Geologically significant information from routine analysis of the midinfrared spectra of diamonds. Int. Geol. Rev. 37, 95-110.

Menzies, A.H., Milledge, H.J. \& GuRney, J.J. (1998): Fourier transform infrared (FTIR) spectroscopy of Newlands 
diamonds. In Seventh Int. Kimberlite Conf. (Cape Town), Extended Abstr., 576-578.

Meyer, H.O.A., Milledge, H.J., Sutherland, F.L. \& KenNewell, P.J. (1997): Unusual diamonds and unique inclusions from New South Wales, Australia. Russ. Geol. Geophys. 38, 305-331.

Milledge, H.J., Mendelssohn, J.I., Boyd, S.R., Pillinger, C.T. \& SEAL, M. (1989): Infrared topography and carbon and nitrogen isotope distribution in natural and synthetic diamonds in relation to mantle processes. In Workshop on Diamonds. Twenty-Eighth Int. Geol. Congress (Washington), 55-60 (extended abstr.).

ORLOV, Yu.L. (1963): Morphology of Diamond. Akad. Nauk SSSR Publishing House, Moscow, Russia (in Russ.).

Plotnikova, S.P. \& KlyUeV, Yu.A. (1986): Optical absorption and luminescence of diamonds with a fibrous structure. Mineral. Zh. 8(2), 31-38 (in Russ.).

Robertson, R., Fox, J.J. \& Martin, A.E. (1934): Two types of diamonds. Philos. Trans. R. Soc. A232(719), 463-535.

SCARRATt, K. \& Fritsh, E. (1992): A note on diamond types. Gems \& Gemology, Spring 1992, 38-42.

Shatsky, V.S., Zedgenizov, D.A., Yefimova, E.S., Rylov, G.M., De Corte, K. \& Sobolev, N.V. (1999): A comparison of morphology and physical properties of microdiamonds from the mantle and crustal environments. In Proc. Seventh Int. Kimberlite Conf. 2 (J.J. Gurney, J.L. Gurney, M.D. Pascoe \& S.H. Richardson, eds.). Red Roof Design, Cape Town, South Africa (757-763).

Smirnov, G.I., KLyUev, Y.A. \& KAminsky, F.V. (1986) Some features of diamond crystals from the Premier kimberlite pipe, South Africa. Mineral. Zh. 8(4), 69-74 (in Russ.).

Sobolev, E.V. (1978): Nitrogen centers and the development of natural diamond crystals. In Problems of Lithosphere and Upper Mantle Petrology (V.S. Sobolev, ed.). Nauka Press, Novosibirsk, Russia 245-254 (in Russ.).

\& LisoIvan, V.I. (1971): Impurity centers in diamond. In VIII Sci. Conf. (Novosibirsk) Abstr., 60-61 (in Russ.).
SpeTsius, Z.V. (1999) Two generations of diamonds in eclogite xenoliths from Yakutia. In Proc. Seventh Int. Kimberlite Conf. 2 (J.J. Gurney, J.L. Gurney, M.D. Pascoe \& S.H. Richardson, eds.). Red Roof Design, Cape Town, South Africa (823-828)

TAKAGI, M. \& LANG, A.R. (1964): X-ray Bragg reflexion, spike reflexion and ultra-violet absorption topography of diamonds. Proc. R. Soc. London A281(1386), 310-322.

Taylor, W.R., Canil, D. \& Milledge, H.J. (1996): Kinetics of Ib to IaA nitrogen aggregation in diamonds. Geochim. Cosmochim. Acta 60, 4725-4733.

JAQUES, A.L. \& RIDD, M. (1990): Nitrogen-defect aggregation characteristics of some Australian diamonds: time-temperature constraints on the source regions of pipe and alluvial diamonds. Am. Mineral. 75, 1290-1310.

\& Milledge, H.J. (1995): Nitrogen aggregation character, thermal history and stable isotope composition of some xenolith-derived diamonds from Roberts Victor and Finch. In Sixth Int. Kimberlite Conf. (Novosibirsk), Extended Abstr., 620-622.

Tolansky, S. (1955): The Microstructures of Diamond Surfaces. N.A.G. Press, London, U.K.

Trautman, R.L., Griffin, B.J., TAYLOR, W.R., Spetsius, Z.V., SMith, C.B. \& LeE, D.C. (1997): A comparison of the microdiamonds from kimberlite and lamproite of Yakutia and Australia. Russ. Geol. Geophys. 38, 341-355.

Woods, G.S. (1986): Platelets and the infrared absorption of type Ia diamonds. Proc. R. Soc. London A 407, 219-238.

\& Collins, A.T. (1983): Infrared absorption spectra of hydrogen complexes in Type I diamonds. J. Phys. Chem. Solids 44(5), 471-475.

Zakharchenko, O.D., Kaminskiy, F.V. \& Milledge, H.J. (1996): Internal structure of Arkhangel' Province diamonds. Dokl. Russ. Acad. Sci., Earth Sci. Sect. 341A, 62-68.

Received February 21, 2001, revised manuscript accepted October 19, 2001. 